\title{
The Translation of St Sylvester's Relics from Rome to Nonantola: Itineraries of corpora sacra at the Crossroads between Devotion and Identity in Eighth-Tenth-Century Italy
}

\section{Edoardo Manarini*}

Pope Sylvester I (314-335) became an important figure in the political history of early medieval Italy. His legendary relationship with Constantine I (306-337), the first Christian emperor, played a significant role in establishing his ideological prominence. Declared a saint of the early Roman Church, Sylvester's relics did not gain much attention until the middle of the eighth century, when they became a source of competition. On the one hand, Roman popes venerated his body in the monastery of St Stephen and St Sylvester, founded by Pope Paul I around 760 inside the Eternal City; on the other hand, the Lombard king Aistulf and his brother-in-law, Abbot Anselm, claimed to have brought Sylvester's relics north, in order to have them buried in Anselm's newly founded monastery of Nonantola in the Po Valley. Scholars would appear to have overlooked this major issue when investigating the relationship between Lombard elite society and Roman popes in the eighth century. This article will therefore consider the dates, forms, and narratives of the translatio of St Sylvester in order to evaluate Nonantola's political and ideological involvement in this "holy « movement. The main argument is that through the "journey « of Sylvester's relics within the Lombard kingdom, King Aistulf was able to increase his prestige and political influence. For its part, Nonantola rewrote the history of its origins by centring it on the relics of the Constantinian pontiff and those of Pope Hadrian I, in order to claim political and spiritual primacy throughout the medieval period.

Keywords: Carloman and St Sylvestre on Mount Soratte; translations of relics; St Sylvester of Nonantola; hagiography; Pope Sylvester I; Lombard kingdom; St Sylvester in Capite; Pope Paul I

\footnotetext{
* Correspondence details: Edoardo Manarini, Dipartimento di Studi Storici, Università di Torino, Palazzo Nuovo -
} Via S. Ottavio 20, 10124 Torino, Italy; email: edoardo.manarini@unito.it. 
In recent times, the role of royal abbeys and monasteries in the political context of early medieval Italy has been examined from the innovative perspective of fiscal estates. ${ }^{1}$ This strand of research relates to the broader topic of fiscal properties in the kingdom of Italy under the Lombards and Carolingians. In recent years the topic in question has attracted renewed attention from historians interested in assessing the extent of such properties, their distribution and their economic and political value for royal power holders. This renewed perspective on public assets has also made it possible to acquire a different awareness of the role of royal abbeys and monasteries, which are now acknowledged to be an integral part of the system. ${ }^{2}$ After the vain attempts made by the Lombard king Liutprand (712-744) to safeguard the royal patrimony against possible unlawful acts at the hands of minor officials, the actores of the kingdom, the brothers Ratchis (744-749/756-757) and Aistulf (749-756) sought to find another way to ensure exclusive royal control over fiscal properties. ${ }^{3}$ The two kings followed a strategy based on exceptions that entailed the founding or endowment of large monasteries with considerable public resources, as a way of freeing them from the control usually exercised by the actores regni. This is the case with St Sylvester of Nonantola, whose founder, Anselm, obtained very substantial fiscal endowments from his brother-inlaw, in areas ranging from the Apennines to the Po. ${ }^{4}$

These powerful and wealthy monastic foundations, of course, also carried crucial spiritual power within the kingdom, especially in relation to the conduct and prestige of individual kings. The prayers recited by the monks and devotion to the saints they venerated in their churches constituted a constant and tangible source of support for the stabilitas regni of early medieval kings. It is within this context that we can best appreciate Paul the Deacon's account of how King Liutprand organised an expedition to Sardinia to retrieve the remains of St Augustine, which had been brought to the island by African bishops exiled by the king of the Vandals Thrasamund in $486 . .^{5}$ In the early eighth century, "Saracen « raids became increasingly destructive, even in Sardinia, ${ }^{6}$ also threatening the saint's relics in their new location in the city of Carales (Cagliari), which seemed no longer safe enough to house such an important treasure for Christendom as a whole. The Lombard king therefore had Augustine's bones retrieved and then buried, with all honours, in the monastery of St Pietro in "Ciel d'oro " near Pavia, a symbol of royal power at the very heart of the kingdom of Italy. ${ }^{7}$

In this article, I would like to retrace the story of the relics of the pope saint Sylvester I (314-335) in the eighth century. Like Augustine, bishop of Hippo Regius, after his death Sylvester was transported to various places, evidently for the purpose of exploiting the symbolic, religious and political value of his relics, insofar as the papal tradition had attributed to this pontiff the conversion of Emperor Constantine, and hence of the whole empire, as

See Lazzari, Patrimoni femminili; Lazzari, Tutela del patrimonio fiscale; Loré, Monasteri, re e duchi. On fiscal estates in the early middle ages, see Bougard and Loré, Biens public; Tomei and Vignodelli, "Dark Matter«.

5 Bede, De temporum ratione, 66, ed. Jones, 535; Paul the Deacon, Historia Langobardorum, 6.4, ed. Bethmann and Waitz, 181. See Di Muro, Uso politico; Stone, St. Augustine's Bones; Tomea, Intorno a S. Giulia, 34-36.

6 Cosentino, Byzantine Sardinia, 351.

7 Pani Ermini, La Sardegna, 300. 
early as the fifth century. ${ }^{8}$ According to the Roman perspective, Pope Sylvester I was the linchpin of the "Constantinian turn «, insofar as he was responsible for the emperor's conversion. After embracing the new religion according to the Roman faith, Constantine was able to support Christianity throughout the Roman world and to assign Rome undisputed primacy within Christendom. However, the historical sources paint a substantially different picture, in which no particularly significant events stand out in Sylvester's twenty-year-long pontificate. ${ }^{9}$ Sylvester did not take part in the two great ecumenical councils held during his papacy, the Council of Arles in 314 and that of Nicaea in 325, nor did his legates play any notable role. ${ }^{10}$ The most reliable historical information about Constantine's baptism is provided by St Jerome, who draws a different picture still: in all likelihood, the emperor was baptised only a short time before his death and certainly embraced the Arian brand of Christianity through the influence of the Arian bishop Eusebius of Nicomedia. ${ }^{11}$ The whole legend of Sylvester, therefore, was fabricated for the purpose of obliterating the memory of Constantine's Arian baptism and of changing his story by placing Rome and its bishops at the centre of Christendom. Starting with accounts of Constantine's baptism, the legend soon took shape in a first written form, which scholars date to the years between the late fifth century and the beginning of the sixth, during Symmachus' pontificate (498-514). ${ }^{12}$ Over time, this initial core expanded considerably, developing into the Silvesterlegende. ${ }^{13}$ Sylvester became a confessor and champion of orthodoxy who had led an exemplary life, performed miracles, triumphed in disputes with demonic creatures, and finally received the Donation of Constantine ${ }^{14}$ We find all this in the so-called Actus Silvestri (AS), which became a key text in the development of Roman Catholic Christianity. At various moments in the Early Middle Ages, Roman pontiffs were to draw upon and revive the veneration of Sylvester, to suit contingent political aims and memorialisation strategies. It is within this framework that the story of St Sylvester's relics and their movements takes place. ${ }^{15}$ But things are somewhat more complicated and contradictory, since throughout the Middle Ages - and even beyond two major monasteries vied for his remains: the Abbey of St Sylvester of Nonantola and the Roman monastery of St Sylvester in Capite.

8 See also, for further readings, Pohlkamp, Kaiser Konstantin; Canella, Gli Actus Silvestri; Wirbelauer, Riche mémoire. On the account provided by the Liber Pontificalis on the life of Sylvester I (n. 34), see McKitterick, Rome and the Invention, 97-100.

9 Canella, Gli Actus Silvestri tra Oriente e Occidente, 241.

10 Scorza Barcellona, Silvestro I.

11 Jerome, Chronicon, a. 337, ed. Helm, 234. In his continuatio of Eusebius of Cesarea's Historia Ecclesiastica, Rufinus of Aquileia re-elaborated the figure of Constatine in a doctrinal key, while avoiding the story of the baptism: Canella, Gli Actus Silvestri tra Oriente e Occidente, 247.

12 Canella, Gli Actus Silvestri tra Oriente e Occidente, 242.

13 See Levison, Konstantinische Schenkung.

On the category of confessor saints, see Bartlett, Saints and Worshippers, 16-19.

On the hagiographical genre of translationes, see Heinzelmann, Translationsberichte. An overview of the development and regulation of the veneration of relics in the Early Middle Ages is provided in this issue by Veronese and Zornetta, Holiness on the move. On translations of relics in Lombard and Carolingian Italy, see Tomea, Intorno a S. Giulia; Vocino, Traslazioni di reliquie; Veronese, Rispetto delle leggi. 
The aim of my article is to consider dates, actions and narratives associated with the translatio of St Sylvester in order to evaluate the political and ideological implications of this "holy « movement. First, I will examine the hagiographical dossier from Nonantola, and particularly the text about the translatio, for the purpose of setting the account of King Aistulf and Abbot Anselm's transfer of Sylvester's body in the political context of the mid-eighth century. ${ }^{16}$ Secondly, after a short investigation of the relations between the monastery of St Sylvester in monte Soracte and Carloman son of Charles Martel, I will turn to the Roman side, by examining the papal version of the event, which took place after the incursion by the Lombard army. The main sources here are the lives of Popes Stephen II and Paul I featured in the Liber Pontificalis (LP), some letters which these pontiffs sent to the Frankish king Pippin, and documents pertaining to the founding of the monastery of St Sylvester in Capite. Lastly, returning to Nonantola, I will analyse how the monastic community responded to this dispute, and particularly how it redeveloped the memory of the translation of the relics and of the very founding of the abbey in accordance with new political requirements that emerged over the course of the Middle Ages.

\section{King Aistulf and the Nonantolan translatio}

The Acta sanctorum of Nonantola and the Text of the translatio Silvestri

In the medieval period, the Abbey of Nonantola boasted a rich and valuable library. ${ }^{17}$ This was first established by its founder Anselm (c.730-803) in the early years of the community, and it was then enlarged by his successors through acquisitions and the work carried out by copyists in the adjacent scriptorium. In the modern age most of the codices were gradually transferred to Rome and today the abbey holds only three manuscripts: ${ }^{18}$ a late eleventhcentury Gradual ${ }^{19}$ the so-called "Gospel Book of Matilda of Tuscany«, also from the late eleventh century; ${ }^{20}$ and the hagiographical codex entitled Acta sanctorum.

This codex was bound in the eighteenth century by putting together two existing manuscripts. In total it comprises four separate codicological units, which, on palaeographical grounds, can be dated to the years between the late tenth century and the beginning of the twelfth. ${ }^{21}$ These quires bring together all the forms of veneration and hagiographical legends associated with the abbey. In the early years, these legends must have been transmitted in a purely oral form. Then, between the tenth and eleventh centuries, the monastic community felt the need to record in writing the hagiographical and memorial material on which it based its identity and its political claims. ${ }^{22}$ A palaeographical analysis of the handwriting can

On the attention Lombards devoted to Roman relics, see Ammannati, La lettera papiracea.

Pollard, "Libri di scuola spirituale«, 332. Branchi, Scriptorium. On the importance of the exploitation of the written word for early medieval monasteries, see Smith, Aedificatio sancti loci.

18 See Branchi, Scriptorium, 115-119.

19 See Branchi, Scriptorium, 230-233.

20 See Branchi, Scriptorium, 254-262.

21 Branchi, Scriptorium, 272; Golinelli, Agiografia monastica. See also the detailed description in Parente and Piccinini, Splendore riconquistato, 125-132.

22 On the practice of historiography at Nonantola, see Frison, Note di storiografia. A survey on the polysemic uses of the past is given in Innes, Introduction: using the past; see also Geary, Phantoms. On relations between oral and written tradition, see Goody, The Power. 
therefore provide a rough date for the texts, although this does not necessarily coincide with the moment in which the narratives were originally drafted. Some internal textual evidence suggests that there is a likely temporal rift between the development of the stories and the redaction of the manuscript we have. Let us take a brief look at the four codicological units before focusing on the one that is of most interest for the present article.

The first codicological unit includes a life of the founder, Abbot Anselm, ${ }^{23}$ a list of the abbots of the monastery, and the transcription of some letters from Pope Gregory the Great (590-604) concerning the autonomy of abbeys with respect to bishops. Although it is most likely that the texts were developed earlier, the handwriting can be dated to the early twelfth century, which makes this section the latest of the four. ${ }^{24}$ Originally it must have made up the final part of another manuscript, as the folia are numbered in Roman numerals from 276 to 283 . The same section was also the last to be bound with the other quires to create the present codex.

The second codicological unit constitutes the earliest and original nucleus of the Nonantolan hagiographical collection. It consists of the Vita sancti Silvestri, written in a measured and calligraphic Carolingian minuscule which may be dated to the last decades of the tenth century. ${ }^{25}$ The text belongs to the so-called C version of the AS. Ever since the research conducted on the complex tradition of this text, first by Wilhelm Levison and later by Wilhelm Pohlkamp, three different versions have been identified, A, B, and C. ${ }^{26}$ The studies in question aimed to produce a critical edition of the text, but this has yet to be published, owing to the large number of witnesses - roughly 300 codices in Latin, 90 in Greek, and several in Syriac. ${ }^{27}$ Version A is the earliest of the three main redactions; it is written in Latin and was first recorded in manuscript form in the tenth century. The second-earliest version is $\mathrm{B}$, which is characterised by a new prologue assigning the work to Eusebius of Caesarea; its manuscript tradition can be traced back to the eighth century. Finally, the most recent version, C, combines the previous two with certain additions; most significantly, it draws upon $L P$. No manuscripts earlier than the mid-ninth century are preserved for this version. ${ }^{28}$

It is noteworthy that the veneration of Sylvester also reached its peak in three moments: the first occurred between the fifth and the sixth century, when Pope Symmachus established the first core of the Sylvester cult and dedicated to the saint the titulus Equitii on the Esquiline (the current church of San Martino ai Monti). ${ }^{29}$ The second occurred in the seventh

23 BHL 541; edited in Vita Anselmi abbatis Nonantulani, ed. Waitz, 566-570; Vita di sant'Anselmo, ed. Bortolotti, 255263.

24 Golinelli, Agiografia monastica, 24.

25 Branchi, Scriptorium, 273. The hypothesis of the end of the tenth century is proposed by Golinelli, Agiografia e culto, 33; instead inclined towards the eleventh century are Ludwig Bethman in Vita Anselmi abbatis Nonantulani, ed. Waitz, 566; Gaudenzi, Monastero di Nonantola, 279; Bortolotti, Antica vita, 178.

26 See Levison, Konstantinische Schenkung; Pohlkamp, Tradition und Topographie.

27 Canella, Gli Actus Silvestri tra Oriente e Occidente, 242.

28 Canella, Gli Actus Silvestri, 5. It is also the only one printed in Mombritius, Sanctuarium sive Vitae Sanctorum, ed. Quentin and Brunet, 508-531.

29 Canella, Gli Actus Silvestri tra Oriente e Occidente, 242. See Boaga, Complesso titolare. On the division of the city of Rome in twenty-five tituli, see McKitterick, Rome and the Invention, 57; Guidobaldi, Organizzazione dei tituli. 
century, under Sergius I's pontificate (687-701), when there is evidence of the existence of an oratory dedicated to St Sylvester in the Lateran palace. ${ }^{30}$ Finally, the third moment was in the mid-eighth century - the very period we are focusing on - when Pope Paul I founded the monastery of St Sylvester in Capite and Pope Hadrian I officially recognised the $A S^{\prime}$ narrative by mentioning it in two letters, addressed to Emperor Constantine VI (790-797) and Charlemagne (768-814). ${ }^{31}$ Until a critical edition of this text becomes available, it will be impossible to draw a close correspondence between these three moments and the different redactions of the text. However, as we shall see in the following pages, interesting correlations can be found between the political events of the eighth century and redaction $\mathrm{C}$, the earliest manuscripts of which date from the middle of the following century. In the Nonantolan hagiographical codex, therefore, we find a late tenth-century redaction of version C, accompanied by an account of the translatio of Sylvester's body to Nonantola in the mid-eighth century. ${ }^{32}$

The third codicological unit is devoted to the veneration of the martyr saints Synesius and Theopompus of Jerusalem, whose bodies were transferred to Nonantola from a small church in the Veneto attached to the monastery after the Hungarian invasions of the early tenth century..$^{33}$ The text covers the passio of the two martyrs, the translation of the relics to Nonantola, and the miracles worked by the two saints' bodies. ${ }^{34}$ It may be dated to the mid-eleventh century. ${ }^{35}$ This account is the most original one in the context of the Nonantolan hagiography, as it draws more directly upon the Benedictine hagiographical tradition, leaving aside the usual political and patrimonial issues recurring in the other texts.

Also dating from roughly the same period is the fourth and last codicological unit, which presents the Constitutum Constantini and the life of Pope Hadrian I. With the addition of the Constitutum to the Nonantolan hagiographical tradition, we have the Silvesterlegende in all of its various constitutive elements: the $A S$, the translatio, and, of course, the Constitutum Constantini, which represents the final redevelopment of the relations between Sylvester and Constantine. ${ }^{36}$ This last account was put together between the eighth and the ninth century, probably in a Roman milieu. ${ }^{37}$

30 Liber Pontificalis, 1.86, ed. Duchesne, 371.

31 Canella, Gli Actus Silvestri tra Oriente e Occidente, 245-246.

32 BHL 7736, 7736a, 7737; De translatione sancti Silvestri, ed. Bortolotti, 269-271.

33 See Bellelli, I codici latini.

34 BHL 8118 (passio), 8115 (translatio)

35 Branchi, Scriptorium, 273.

36 See Constitutum Constantini, ed. Fuhrmann.

37 On the Constitutum Constantini see Levison, Konstantinische Schenkung. Although it was probably composed in a Roman context, its composition among the Franks has, however, been proposed. On the latter hypothesis, see Fried, Donation of Constatine; recently, the Roman origin was maintained in Goodson and Nelson, The Roman contexts. In 1974, Pietro De Leo proposed that the Constitutum was written in Rome by a Greek monk who fled there after the iconoclastic crisis, maybe staying in the Greek monastery of St Sylvester in Capite: De Leo, Constitutum Constantini. 
The life of Pope Hadrian I is narrated in two versions, in verse and in prose ${ }^{38}$ The contents are roughly the same, but, of course, the second version is more detailed and it is intended for a learned public, mostly consisting of clerics. The one hundred verses of the poetic version of the life are instead addressed to the concio plebis, the assembly of the people of Nonantola, who would probably listen to a recitation of the pope's deeds on what, according to the abbey's liturgical calendar, was his feast day, possibly 8th July. ${ }^{39}$ This was believed to be the day of his death - at least at Nonantola - because of the fortuitous circumstances of Pope Hadrian III's death near the monastery in 885 on that very day..$^{40}$ The memory of Pope Hadrian III's death - and of the burial of his body in the abbatial church - was thus intentionally kept vague by the monks in order to establish the local veneration of Hadrian I. Scholars investigating the two texts have long wondered which was composed first. Judging from the textual motifs and the two modes of fruition, it is most commonly held nowadays that the two texts were composed around the same time, with two different target audiences in mind. ${ }^{41}$

Let us now return to the section dedicated to St Sylvester in order to add some philological details before dealing with its content. As already mentioned, the great hagiographical codex from Nonantola devotes an entire section to St Sylvester's life in its C version. It is noteworthy that this is the only redaction to mention the pontiff's death and his burial in the Priscilla cemetery along the Via Salaria, a few miles north of Rome. ${ }^{42}$ This detail may have been added to the legend in the eighth century, which is to say when St Sylvester's relics started attracting some interest even outside the Church of Rome: the latter would have felt the need to reaffirm that their current location was the original one, which had remained unchanged since the fourth century.

Likewise, the account of the translation of the relics is recorded in a small number of codices, all belonging to redaction C. In his edition of the entire Nonantolan hagiographical corpus, produced in the late nineteenth century, Pietro Bortolotti identified another six witnesses in addition to the Nonantolan one - three preserved in France, three in Belgium. ${ }^{43}$ From a palaeographical standpoint, the version preserved at Nonantola is the earliest, since it is written in a late tenth-century Caroline minuscule. ${ }^{44}$ Over the course of its history, the

38 BHL 3737, 3738; both texts are edited in Gaudenzi, Monastero di Nonantola, 280-312.

39 In the same quire as the life of Abbot Anselm, a mass for Pope Hadrian's feast day has also been copied; see Golinelli, Agiografia e culto, 45 .

40 Liber Pontificalis 2.112, ed. Duchesne, 191; Annales Fuldenses, a. 885, ed. Pertz, 401-402.

41 Ropa, Agiografie e liturgia, 43-44.

42 Canella, Gli Actus Silvestri tra Oriente e Occidente, 242; Scorza Barcellona, Silvestro I. On the matrona Priscilla and the cemetery named after her, see McKitterick, Rome and the Invention, 91, 122.

43 Bortolotti, Antica vita, 178. Quoting the BHL online database, Golinelli (Agiografia monastica, 28) indicates sixteen manuscripts attesting the first version of the translatio (BHL 7736), one for the second (BHL 7736a) and twelve for the third ( $B H L$ 7737). However, a first analysis of the catalogues of the various libraries has shown that these data are groundless.

44 Bortolotti, Antica vita, 178, but the dating to the late tenth century is proposed by Golinelli, Agiografia e culto, 33. 
manuscript must also have served a liturgical function, since in the margins, for the whole length of the text, the pages bear rubrics dividing it by lectiones. Their enumeration, which from the third lectio to the last, the eighth, is given in Arabic numerals, enables us to date the manuscript to the thirteenth century, and hence to confirm the enduring use of this text in the everyday life of the monastic community. ${ }^{45}$

Scholars have yet to examine the philological relations between the Nonantolan witness and the other six, later, transalpine manuscripts, so it is impossible to propose a stemma codicum for the text. As far as dates are concerned, Troyes MGT anc. 7, Paris BNF lat. 3788 and Bruxelles KBR 5519-5526 have been dated to the twelfth century; Namur MAAN vil. 15 and Bruxelles KBR 206 to the thirteenth; and Bruxelles KBR 8515 to the fifteenth. Bortolotti thus based his edition on the earliest Nonantolan witness - even though he regarded it as more recent than the latest studies have shown it to be - and was only able to check the variants in three of the six transalpine manuscripts. ${ }^{46}$ Bortolotti also discovered a recensio brevior of the text in a codex from the Philipps Collection of the Brussels Royal Library (KBR), ${ }^{47}$ which he believed to belong to a different tradition from that of the Nonantolan version present in the other manuscripts. ${ }^{48}$

Let us now turn to examine the content of the translatio Silvestri and try to set it in its historical context, since the veneration of Pope Sylvester I stretched back to the very origins of the abbey. The monks maintained that the saint's body had been retrieved in Rome by the Lombard king Aistulf, who had then handed it over to his brother-in-law Anselm, in order for it to be preserved in his monastery. In the early years multiple names were associated with the abbey, but in the tenth century Nonantola exclusively came to be named after St Sylvester. In the following section, I will discuss the events which occurred in the mideighth century, as these constitute an essential starting point for grasping the memorial and identity-building strategies adopted by the monks over the course of the following centuries.

\section{King Aistulf's Military Expedition of 755}

The events related to the translatio took place in the context of King Aistulf's military operations against the Roman duchy between 755 and 756, when Lombard troops occupied the territory and besieged Rome for almost three months. In the early years of his reign (749752), Aistulf pursued a bold expansionist policy which enabled him to conquer almost all of the central northern Italian territories still nominally under Constantinople's control. ${ }^{49}$ The king then took advantage of his dominant position to strike a forty-five-year peace agreement with the newly elected Pope Stephen II. ${ }^{50}$ However, the situation changed radically for

45 On the liturgical use of the translatio, see Tiraboschi, Storia dell'augusta badia 1, 67; on Nonantolan liturgy in general, see Ropa, Agiografie e liturgia.

46 Troyes MGT anc. 7, Namur MAAN vil. 15 and Bruxelles KBR 206.

47 Catalogus codicum hagiographicorum Bruxelliensis 2, 437-439. See the edition of the text in Translatio Sancti Silvestri, ed. Bortolotti, 272.

48 Bortolotti, Antica vita, 178.

49 On mid-eighth-century political events in Italy involving the Lombards, the Franks and Rome, see Delogu, Lombard and Carolingian Italy, 294-300; Gasparri, Italia longobarda, 100-106. A specific enquiry on Aistulf's political and military choices is provided by Hallenbeck, Pavia and Rome, 52-85. On the 756 siege of Rome, see Hallenbeck, Rome under attack.

50 See Noble, Republic of St. Peter, 71-78; Hallenbeck, Pavia and Rome, 52-59. 
Aistulf following the pontiff's negotiations with Pippin III - who had just supplanted the Merovingian Childeric III on the Frankish throne $(751)^{51}$ - and his first Italian expedition in $754 .{ }^{52}$ The siege of Rome may have been an attempt by the Lombard king to force Stephen II to grant the Lombards a more favourable agreement than the one they had been compelled to sign the previous year, under the threat of Pippin's army. ${ }^{53}$

The hagiographical narrative offers the following version of the story: after founding the monastery of Nonantola, which housed phalanges of monks right from the start, ${ }^{54}$ Anselm decided to make the abbey the final resting place for St Sylvester's limbs - the Latin uses the word artus, which I will return to shortly. Anselm therefore asked the king, who found himself in the territory of the Roman duchy, to authorise the transportation of the holy relics from Rome. In this passage we catch a glimpse of the later Carolingian laws concerning the transfer of relics, which was only deemed legal if sanctioned by the authorities. ${ }^{55}$ Aistulf agreed and so Anselm, escorted by a group of monks, was able to retrieve Sylvester's body - the text now uses the word corpus - and to take it back to Nonantola in order to bury it in the abbey's church. As though to confirm the rightfulness and lawfulness of the translation, the saint already started working various miracles on the way back, showing his approval of Anselm's actions. ${ }^{56}$

The narrative, then, is quite straightforward: in order to increase the aura of sanctity and symbolic weight of his monastery, the founder decided to obtain one of the most coveted and valuable relics in Christendom. The circumstances were favourable because Aistulf was already near Rome - the hagiographer casually glosses over the very earthly military deeds in which the king was engaged - and was bound to consent to his brother-in-law's operation. As though heading a procession, Anselm entered Rome and cum reverentia removed the saint from his original grave. I have emphasised the two terms used by the Nonantolan hagiographer, artus and corpus, because the choice of these words might express a sort of excusatio to the Church of Rome and the pope, the previous keepers of the relics; as such, it might reflect a concern to avoid the charge of performing a furtum sacrum: ${ }^{57}$ Anselm had set off with the intention of retrieving only the saint's limbs, which is to say one or more portions of what remained of his mortal body. In all likelihood, all that remained was bones, seeing that 400 years or more had gone by. It was only for reasons beyond Anselm's control - namely Aistulf's desire to retrieve the relics and the dilapidated condition of the Roman cemetery (although the hagiographer does not dwell on such matters) - that the Nonantolan mission ultimately returned with the whole corpus, which is to say with all that remained of Sylvester's body.

51 See Wood, Merovingian Kingdoms, 290-292.

52 See Gasparri, Italia longobarda, 105-107.

53 Hallenbeck, Rome under attack, 206.

54 On the historical consistency of this hagiographic topos, see Schmid, Anselm von Nonantola.

55 See Veronese, Rispetto delle leggi. On Carolingian regulation on the cult of saints, see Fouracre, Origins of the Carolingians.

56 De translatione sancti Silvestri, ed. Bortolotti, 269-271.

57 On the concept, see Geary, Furta sacra, 3-27. 
This text supports two distinct levels of reflection on the events reported. First, this version of the story is told from the perspective of Nonantola, according to the earliest reconstruction. I will get back to later redevelopments shortly. One piece of historical information that seems plausible, as it is also reported by the Roman sources, is the role played by King Aistulf in the relics episode. The first level of reflection, therefore, concerns the political behaviour of the leading actors of the mid-eighth century. In other words, it consists in reflecting on the religious and symbolic motivations behind the retrieval of the relics of St Sylvester and their placement in the Abbey of Nonantola, which had been founded through the crucial contribution of Aistulf.

In a charter granted to the abbey by Louis the Pious and Lothar in 825, Anselm's church is said to have been dedicated to omnium apostoloroum (to all the apostles), and to be the place where the body of St Sylvester rests, »in quo beatus Sylvester corpore requiescit «. ${ }^{8}$ Only a few decades later, then, do we find some indirect evidence attesting to the translation of the relics. Given that we have no references to any translation from either the Carolingian period or the reign of Desiderius (757-774), Aistulf's successor, St Sylvester's relics - or part of them - must have been transported from Rome to Nonantola in the period indicated by the Nonantolan narrative. Just as King Liutprand (712-744) decided to retrieve the remains of a Church Father in order to enshrine them in the church in the capital of his kingdom, possibly the church dearest to him, ${ }^{59}$ so King Aistulf sought to implement a similar plan by retrieving from Rome the relics of Sylvester, the pope who had converted Emperor Constantine, and hence the whole West, to Christianity. ${ }^{60}$ As we shall see in the following section, the memory of St Sylvester and the tradition associated with him were to become a source of competition with the Carolingians, who, in those years, were busy consolidating and legitimising their royal power. ${ }^{61}$

Secondly, another level of reflection pertains to the memorial and identity-building discourses developed by the monastic community over the course of its history. The veneration of the saint at Nonantola is attested from the ninth century, when at least two copies of the $A S$ had been copied following the $\mathrm{C}$ version, but without any reference to the relics of Sylvester. ${ }^{62}$ It then intensified over the course of the tenth century, when the life and translatio Silvestri were copied in the manuscript which later became the ancient section of the Acta sanctorum. In this respect, the reception of Carolingian regulations in the narrative adaptation of the account suggests that this was first laid down before the drafting of the current Nonantolan manuscript, possibly in the late ninth or early tenth century. The cult was intended to celebrate the figure of Sylvester by establishing a direct parallel between the pope

58 DD Lu I, ed. Kölzer, n. 249; $R I$ 1, ed. Mühlbacher and Lechner, 321. The dedication to Sylvester is already mentioned in Charlemagne's diplomas for Nonantola: the first original is the second granted by the king in 780: RI 1, ed. Mühlbacher and Lechner, 96; DD Kar I, ed. Mühlbacher, n. 131.

59 Di Muro, Uso politico.

60 On Aistulf's symbolic and ideological programme, see Harrison, Political rhetoric, 250-251.

61 On the Pippinid conquest of Frankish royal power, see Wood, Merovingian Kingdoms, 287-292; Goosmann, Memorable Crises, 159-204; Fouracre, Long shadow; Ricciardi, Re e aristocrazia.

62 St. Gallen 567 and Bamberg patr. 20. See Bischoff, Manoscritti nonantolani, 111-114; Branchi, Scriptorium, 175178. 
and the founder Anselm, and between Constantine and the Lombard king Aistulf, who was also praised as the founder of the abbey. This kind of hagiographical discourse was essentially designed to provide ideological support to the political claims of the abbey, whose political and spiritual influence had been waning significantly over the course of the tenth century.

\section{The Roman Account: Reticence and Sanctity}

St Sylvester in Monte Soracte and Carloman's Retirement

Before carefully examining the Roman version of what happened in 756 , we must turn our attention to another monastic institution dedicated to the Constantinian pontiff, whose history appears to be closely related to the events we are investigating. In this case, what captures our interest is not so much the saint's relics, as the tradition of his veneration in the Roman area and its evolution over the course of the eighth century. The Roman monastery of St Sylvester in monte Soracte became particularly important for the cult of St Sylvester in this period through the action of Carloman, maiordomus of the Frankish kingdom of Austrasia (741-747), eldest son of Charles Martel and brother of Pippin III. ${ }^{63}$

Mount Soratte is a limestone mountain that dominates the Roman countryside. It rises in the Tiber Valley north of the Eternal City and its slopes were already a place of religious worship in Antiquity. The first Christian traces date back from the earliest days of Christianity in Rome and Latium, when many hermits established themselves on the summit of the mountain to flee the world and engage in contemplation. ${ }^{64}$ Benedict, a monk of S. Andrea al Soratte who wrote a chronica in the late tenth century, ${ }^{65}$ traces the founding of the aecclesia of St Sylvester in monte Soracte back to Damasus' pontificate (366-384). He credits the pope himself with having established the monastery, to mark the site where Sylvester had sought refuge from Constantine's persecution, ${ }^{66}$ even if, according to his tale, the latter emperor was also involved in the foundation of the church. ${ }^{67}$ This information, which is not recorded anywhere else, is clearly inspired by the Silvesterlegende laid down in the $A S{ }^{68}$ The first historical attestation dates from the late sixth century, when Pope Gregory the Great described the life and miracles of a monk residing in the monastery "quod Soracte monte situm est" in the first book of his Dialogi. ${ }^{69}$ The monk in question was Nonnosus, the praepositus of the monastery around the mid-sixth century, who had already given proof of his profound saintliness and miraculous powers during his lifetime. ${ }^{70}$

63 On Carloman's political career, see McKitterick, Frankish Kingdoms, 33-34; Goosmann, Politics and penance.

64 Canella, Luoghi di culto, 329.

65 See Chronicon di Benedetto, ed. Zucchetti, VII-XX.

66 Chronicon di Benedetto, ed. Zucchetti, 9.

67 Chronicon di Benedetto, ed. Zucchetti, 6.

68 Mombritius, Sanctuarium sive Vitae Sanctorum, ed. Quentin and Brunet, 511.

69 Gregory the Great, Dialogi, 1.7, ed. de Vogüé, 66.

70 See Acta Sanctorum, 2nd September. 
The most detailed source concerning the history of the monastery between the sixth and the eighth century is undoubtedly monk Benedict's chronicle, even though it was only composed in the late tenth century. In addition to drawing upon other historical accounts in relation to earlier periods - including the Venerable Bede, the $L P$, and Gregory the Great $-^{71}$ it is most likely that Benedict had exclusive access to legends and oral accounts of the history of the first monastery in monte Soracte and that he incorporated them into his work. However, by the time of his writing, the dedication of the monastery to St Sylvester had certainly been established for at least two centuries, so much so that the pontiff's tomb could be placed inside the abbatial church, along with a commemorative tombstone. ${ }^{72}$ It is reasonable to assume, then, that the attribution of the dedication of the monastery to Sylvester was an effort on the chronicler's part to backdate the cult of the saint $a b$ origine. Besides, the very legend featured in the $A S$ affirms the holiness of Mount Soratte for the first time by stating that St Peter and St Paul appeared to the emperor in a dream, ordering him to seek out Sylvester, whose hiding place they revealed to him. ${ }^{73}$ Given that the two saints' intervention represents the centrepiece of Constantine's conversion story, Giuseppe Tomassetti has suggested that the first church erected on the slopes of the mountain was dedicated to Rome's two most prominent saints. ${ }^{74}$

In this respect, what we know about the cult of St Nonnosus seems to confirm the hypothesis that the figure of Sylvester was originally assigned less weight. Nonnosus would appear to have been the primary object of devotion in the earliest monastic community in monte Soracte, even though his name is always associated with that of Sylvester. ${ }^{75}$ If we once again turn to the only source close to the events in question, we realise that Pope Gregory makes no mention of the dedication of the monastery, as the focus of his narrative is specifically on the saint's life and deeds. After the miracles performed in his own lifetime, according to Pope Gregory, once deceased, Nonnosus' body was buried in the church on the slopes of the mountain, where he was venerated as a saint. ${ }^{76}$ In the mid-eighth century even King Ratchis (744-749) and Queen Tassia made a pilgrimage to Nonnosus' tomb. Beyond Ratchis' veneration for the saint, this journey also shows that the Lombard king was always eager to control the shifting southern borders of his kingdom, and always kept an eye on Rome and southern Italy. ${ }^{77}$ To strengthen Nonnosus' link with the monastery, monk Benedict recounts that while the royal couple was praying by his relics, the saint performed a miracle by freeing a man from the evil spirits possessing him. ${ }^{78}$ 32-34.
Chronicon di Benedetto, ed. Zucchetti, XXII-XXIII.

Chronicon di Benedetto, ed. Zucchetti, 10.

Mombritius, Sanctuarium sive Vitae Sanctorum, ed. Quentin and Brunet, 511. See also Canella, Storia e leggenda,

Tomassetti, Della campagna romana, 557; Canella, Luoghi di culto, 329.

See Tomassetti, Della campagna romana, 555-560.

Chronicon di Benedetto, ed. Zucchetti, 22.

See, in this volume, Heath, Aspects of movement and mobility.

Chronicon di Benedetto, ed. Zucchetti, 66. 
In the mid-eighth century, the situation changed drastically and the monastery in monte Soracte acquired European-wide relevance. It was at this time that the abbey came to be unambiguously associated with St Sylvester and his cult, even though no mention of his relics is made in our sources. ${ }^{79}$ Even more interestingly, this link emerges from Frankish sources, those closest to the Carolingian royal household. The Pippinids' interest in the cult of this saint no doubt introduced a significant novelty in the papal tradition of the discourse on Sylvester, since for the first time a political actor outside the Roman milieu appropriated it in order to legitimise his recent acquisition of royal power.

Following his victorious campaign against the Alamanni in $746,{ }^{80}$ according to the $A n$ nales Regni Francorum (ARF), ${ }^{81}$ Carloman confided to his brother Pippin III that he wished to leave the saeculum in order to become a monk. The following year he reached Rome, was tonsured, and founded a monastery dedicated to St Sylvester on Mount Soratte. Some time later, Carloman moved to Monte Cassino and took up the monastic life there.

The version of the $A R F$ in the so-called continuatio Einhardi added two more highly interesting details which, as we shall see, were later rearranged in the last version of the event provided by Einhard's Vita Karoli. The account of the continuatio features a direct reference to the $A S$ - although no mention is made of the Church of Rome - with regard to the reason for Carloman's founding of the Soratte monastery: "ubi quondam tempore persecutionis, quae sub Constantino imperatore facta est, sanctus Silvestrus latuisse fertur «. Carloman would have chosen to move to Monte Cassino after receiving virtuous advice from someone whose identity is not mentioned. ${ }^{82}$ As the narrative of the $A R F$ provides the "official « Carolingian version of the event, ${ }^{83}$ it must be recalled that Carloman belonged to the kinship branch that had lost the contest for the throne. ${ }^{84}$ Nevertheless, the episode brings out powerfully the desire to establish a direct link between the Pippinids, who were seeking to legitimise their royal power after the coup of 751, and the Roman and Christian imperial tradition embodied by St Sylvester.

However, other sources complicate the picture. The Annales Mettenses Priores reveal that the advice in question was offered by Pope Zachary, thereby bringing the pontifical voice into the narrative, which had been noticeably absent in the two previous versions. Like the $A R F$, the Annales Mettenses were drafted in a milieu very close to the Carolingian family: they may have been written by Gisela herself, Charlemagne's sister and the abbess of Chelles. ${ }^{85}$ Their

79 A document from the register of Pope Gregory II (715-731) already records the dedication to Sylvester: Regesta Pontificum Romanorum, 2207, ed. Jaffé et al., 255. However, since it survives only inside the Collectio Canonum of Deusdedit composed in the eleventh century, there is no need to refer to it here; see Kanonessammlung des Kardinal Deusdedit, 3.231, ed. Glanvell, 369.

80 Annales Mettenses Priores, a. 746, ed. Simson, 37. See Becher, Verschleierte Krise.

81 Annales Regni Francorum, a. 746, ed. Kurze, 6.

82 Annales Regni Francorum, a. 746, ed. Kurze, 7.

83 McKitterick, Constructing the past, 115.

84 The Carolingian accounts should therefore be read bearing that in mind, as pointed out by Goosmann, Politics and penance, 53 .

85 See Nelson, Gender and genre. 
account, though, presents the event in a more neutral form, so to speak, by leaving out the figure of Sylvester and focusing the whole action on the pontiff: having decided to leave his kingdom, Carloman moved to Rome, where Pope Zachary ordained him a monk and advised him to withdraw to Monte Cassino and live there under the guidance of Abbot Optatus (750-760) ${ }^{86}$

A very similar narrative, with no references to Sylvester or even Mount Soratte, is featured in the LP's life of Zachary. ${ }^{87}$ It is conceivable that Carloman's plans about Soratte were not received favourably in Rome, both because they would have been viewed as an interference in the cult of Sylvester, and because Stephen II's interlocutor had always been Pippin, not his brother. ${ }^{88}$ So what was later recorded in the $L P$ must be a watered-down version of the event, which already took account of the later compromises struck by the two parties as we shall soon see.

On the Carolingian side, the final rereading of Carloman's actions was provided by Einhard in the Vita Karoli: ${ }^{89}$ probably out of love of the contemplative life, Pippin's brother resigned from the secular government of the kingdom, travelled to Rome in otium, and then - after taking the monastic vows - moved to Mount Soratte. Here, around the church of St Sylvester, he built a monastery in which he hoped to find the tranquillity he was looking for, along with his brothers, who had joined him from across the Alps. However, throngs of noblemen started heading towards Rome from Francia, in order to visit Carloman, to the point that the latter decided to move away to escape the constant disturbance. Leaving Mount Soratte, he reached the monastery of St Benedict at Monte Cassino, where he lived out the rest of his days. ${ }^{90}$

Einhard does not assign the pontiffs any weight in the event but makes sure to distinguish between the existence of a church of St Sylvester on Mount Soratte and Carloman's monastic foundation. This subtle distinction may be regarded as the outcome of the negotiation between the Carolingians and the pontiffs: while being welcomed into the monastic world of Roman central Italy, Carloman did not appropriate the figure of St Sylvester. Once freed from the awkward self- legitimising discourse of the Carolingians, the saint's memory and cult would have remained exclusively connected to the Church of Rome and its popes - had it not been for Aistulf.

86 Annales Mettenses Priores, a. 746-747, ed. Simson, 37-38.

87 Liber Pontificalis, 1.93, ed. Duchesne, 433. On Frankish additions in this $L P$ section, see McKitterick, Rome and the Invention, 210-216.

88 On Pope Stephen II's role in shaping the Carolingian-Roman allegiance, see Noble, Republic of St. Peter, 71-94; McKitterick, History and Memory, 146-148. For his part, Carloman served as Aistulf's envoy at Pippin's court in 754: Hallenbeck, Pavia and Rome, 77-78.

89 Later, Regino of Prüm also told of Carloman. He basically relied on the ARF account (recension B), but also expanded the tale in order to make a hero out of Carloman, an exeplum memorabile; see Goosmann, Politics and penance, 51-53.

90 Einhard, Vita Karoli Magni, 2, ed. Holder-Egger, 4-5. 


\section{Pope Paul I and the Roman Account on St Sylvester's Relics}

Let us now consider the relics episode from the Roman side. ${ }^{91}$ King Aistulf's military operations in the Roman duchy in the late months of 755 are also associated with the removal of the relics by Roman sources, within the Church of Rome (the $L P$ ), ${ }^{92}$ and by the Codex Carolinus. Although the Codex brings together letters which the pontiffs addressed to the Frankish court, the collection was commissioned by Charlemagne. The representation of power and relations which this collection provides should be regarded as a Frankish political statement, albeit one expressed through the papal voice. ${ }^{93}$ However, the picture both these sources paint is an inconsistent one.

First of all, we can rely on three letters which Pope Stephen II sent King Pippin to ask for his aid against Aistulf's incursions into the duchy's territory and for troops to break the siege on Rome. ${ }^{94}$ These letters describe the many acts of devastation perpetrated by the Lombards: outside the city, buildings, churches and monasteries were pillaged and set on fire; monks were murdered and nuns raped and killed; many Romans were seized as slaves or slain. ${ }^{95}$ The life of the pontiff included in the $L P$ adds further details concerning these events:

everything outside the city this pestilential (pestifer) Aistulf devastated with fire and sword, and thoroughly wrecked and consumed it, pressing mightily on so that he could capture this city of Rome. He even dug up the sacred cemeteries of the saints and stole many of their bodies, which was greatly to his own soul's detriment. ${ }^{96}$

Based on the expression "multa corpora sanctorum [...] abstulit", subsequent chroniclers, as well as modern historians, have attributed generic furta sacra to Aistulf designed to breathe new spiritual life into the churches of Pavia and the kingdom through the relics of saints. ${ }^{97}$ The only translation we can identify is precisely that of St Sylvester, although the Roman sources do not mention it explicitly.

A detailed analysis of the LP's account, however, would appear to suggest that the whole passage on Aistulf must be interpreted in the light of the last sentence: »ad magnum anime sue detrimentum «. For obvious reasons, throughout the text the king is portrayed in totally negative terms, as a diabolical figure. ${ }^{98}$ All value judgements aside, the biographer sought to demonstrate that the king's earthly behaviour was bound to have repercussions on his

91 For the earlier papal policy on relics, see Goodson, Building for bodies.

92 A comprehensive analysis of the text is provided by Capo, Liber Pontificalis; and now McKitterick, Rome and the Invention; see also Gasparri, Italia longobarda, 154-164.

93 Gasparri, Italia longobarda, 105. On the Codex Carolinus, see Van Espelo, Testimony of Carolingian rule?

94 Codex Carolinus, 8, 9, 10, ed. Gundlach, 494-503.

95 Codex Carolinus 9, ed. Gundlach, 498-500.

96 Liber Pontificalis, 1.94, ed. Duchesne, 451-452: "Omnia extra urbem ferro et igne devastavans atque funditus demoliens consumsit, imminens vehementius hisdem pestifer Aistulfus ut hanc Romanam capere potuisset urbem. Nam et multa corpora sanctorum, effodiens eorum sacra cymiteria, ad magnum anime sue detrimentum". The quote is from Lives of the Eight-Century Popes, 94, trans. Davis, 68. On this biography, see Gantner, Lombard recension, 68-70.

97 Chronicon Salernitanum, ed. Pertz, 475; Pauli diaconi continuatio tertia, ed. Bethmann and Waitz, 209. An enquiry about the relics Aistulf took can be found in Tomea, Intorno a S. Giulia, 41-46. Doubts as to what actually happened have also been expressed by Goodson, Relics translation, 125.

98 The life of Stephen II also exists in a so-called Lombard recension, which eliminates all the negative adjectives used to describe King Aistulf and the Lombards; see Gantner, Lombard recension; McKitterick, History and $\mathrm{Me}$ mory, 52; Lidia Capo believes that the redaction is of Roman origin: Capo, Liber Pontificalis, 64-65. 
soul. Aistulf's profanation of cemeteries and theft of numerous bodies of saints no doubt represented the culmination of a series of increasingly wicked behaviours certainly destined to seal his damnation. This hypothesis is confirmed by a document issued by Stephen II's successor, his brother Paul I, who ruled as pontiff between 757 and 767. On 2nd June 761, he founded a monastery near an urban residence of his for the safekeeping and veneration of many of the relics buried in cemeteries and catacombs outside the city walls. ${ }^{99}$ This measure had become necessary because of the state of abandonment in which those ancient places of worship lay. The text explains how, in addition to the ravages of time, the tombs had recently suffered devastation at the hands of the Lombards, who had profaned, pillaged and demolished them, stealing the bodies of some saints: "quorumdam sanctorum depredati auferentes secum deportaverunt corpora". Therefore, the Lombard troops would appear to have stolen only some of these relics.

This deed is crucial for the dossier on St Sylvester's relics transmitted by the Roman tradition. The monastery founded by Paul I was dedicated precisely to saints Sylvester and Stephen and was conceived by the pontiff as a means to permanently enshrine the cult of St Sylvester in Rome by combining for the first time a dedication to the saint with the burial of his remains:

ut, quia beatus Silvester christianorum inluminator fidei, cuius sanctum corpus in nostro monasterio a nobis reconditum requiescit, pridem persecutionem paganorum fugiens conversatus est, iustum prospeximus, ut sub eius fuisset ditione, ubi ipsum venerandum requiescit corpus. ${ }^{100}$

To this day, the church preserves its original dedication, having acquired the name of St Sylvester in Capite, meaning precisely St Pope Sylvester I. The foundation charter itself, which is now lost, bore on the verso the date on which the two saints were buried in the new church, shortly after the founding day, 2nd June 761: the corpus of St Sylvester was brought to the monastery the following 9th June, that of St Stephen on 17th August. ${ }^{101}$ The transfer of the relics from the cemetery of Priscilla on the Via Salaria, outside the city of Rome, is further confirmed - as we shall see - by a letter that pontiff Paul I addressed to King Pippin not long afterwards, as well as by the account of this pope's life in the $L P$ :

this holy prelate constructed from the ground up a monastery in his own house in honour of St Stephen the martyr and pontiff and St Sylvester, another pontiff and a confessor of Christ. He built a chapel on to this monastery's upper walls, and with great veneration he deposited their bodies there. ${ }^{102}$

99 Concilia aevi Karolini, 12, ed. Werminghoff, 64-70. On the eighth-century papacy's relics' policy, see Smith, Care of relics; Maskarinec, City of Saints.

100 Codex Carolinus, 42, ed. Gundlach, 556; see also Regesto del monastero di S. Silvestro, ed. Federici, 216-226.

101 Concilia aevi Karolini, 12, ed. Werminghoff, 65.

102 Liber Pontificalis, 1.95, ed. Duchesne, 464: "Hic sanctissimus presul in sua propria domu monasterium a fundamentis in honore sancti Stephani, scilicet martyris atque pontifices, necnon et beati Silvestri, idem pontificis et confessoris Christi construxit. Ubi et oraculum in superioribus eiusdem monasterii moeniis aedificans, eorum corpora magna cum veneratione condidit«. The quote is from Lives of the Eight-Century Popes, 85, trans. Davis, 81. 
To complete the establishment of the cult of St Sylvester from a papal perspective, Paul I also needed to settle the issue of St Sylvester in monte Soracte and of its relationship with the Pippinid dynasty. The only sources about this are two letters which Paul I addressed to Pippin between 761 and 767. As these epistles too come from the Codex Carolinus, it is possible to interpret them on two distinct levels. The first letter, sent between 761 and 762, informs us that Carloman's presence on Mount Soratte was due to Pope Zachary, who had donated the monastery of St Sylvester to him. We further learn that Pippin later asked Paul I to donate the monastery to him, and that the pontiff granted his request. ${ }^{103}$ It is immediately evident that this account conflicts with what the $L P$ states in its life of Zachary, where no mention at all is made of Mount Soratte with reference to Carloman. Perhaps, as he could not deny the latter's involvement in the cult of Sylvester on Mount Soratte alongside his brother, Paul I sought at least to bring this involvement back within the pontifical orbit, by imagining that his predecessor was responsible for Carloman's presence on the mountain. It is more difficult to make sense of Pippin's request that the pope donate the same monastery to him, but it may reflect the king's desire to follow in his brother's footsteps and remain associated with the Roman Christian imperial tradition embodied by Sylvester.

Be that as it may, the issues would appear to have been settled for good shortly afterwards, as the second letter - already mentioned above, and written between 762 and 767 - informs us that the king of the Franks returned the monastery in monte Soracte to the pontiff, that the latter might complete the foundation of his own abbey of Saints Sylvester and Stephen: Pippin granted the pope possession of the other monastery of St Sylvester too "ad laudem Dei et vestri [i.e. Pippin's] memoriam $"{ }^{104}$ To further strengthen the political and ideological-symbolic relations between the Pippinids and the Church of Rome, Paul I enshrined the relic of St Denis which his brother Stephen II had brought back to Rome from Francia as a gift from Pippin in the new monastery of St Sylvester. Not only was an altar dedicated to the first Bishop of Paris inside the church, but his name was added to the dedication of the monastery itself. ${ }^{105}$ The dedication was retained until the twelfth century. ${ }^{106}$

Paul I was thus able to bring together the tradition and cult of St Sylvester in a single place, under solid papal patronage. The memory of the saintly pontiff could only become associated with - and exploited by - the Frankish political authorities through the Church of Rome, which imposed itself as a mediator. The Pippinids/Carolingians thus agreed to leave the figure of Sylvester to the popes because, through their mediation, they would still be able to ensure the kind of legitimation of their own royal power that they had been seeking since the coup of $751 .{ }^{107}$ However, the Codex Carolinus bears witness to Charlemagne's desire to preserve the memory of these events and of his uncle and father's connection with St Sylvester in monte Soracte: echoing earlier Frankish sources, these letters evoke the dynasty's direct relationship with the saintly pontiff.

103 Codex Carolinus, 23, ed. Gundlach, 526-527.

104 Codex Carolinus, 42, ed. Gundlach, 554-556.

105 Hilduin, Libro de sancto Dionysio, ed. Waitz, 3. See Ferrari, Early Roman Monastery, 302-312; Goodson, Rome of Pope Paschal I, 214.

106 Regesto del monastero di S. Silvestro, ed. Federici, 220.

107 On the following developments, such as the choice of Saint Petronilla as the patron saint of the Frankish royal family and Paul I's parrainage to Pippin's daughter Gisela, see Goodson, To be daughter; McKitterick, Charlemagne, Rome and the management. In general, on the ability of the papacy as a political and cultural mediator, see Gantner, Eighth-century papacy. 
The church of St Sylvester in Capite immediately became a place of worship and veneration on account of the many bodies of saints and martyrs - around fifty - which had been brought there from dilapidated cemeteries outside the city. ${ }^{108} \mathrm{~A}$ set of inscriptions still preserved in the churchyard lists the Dies nataliciorum (feast days) of the saints found in the church, divided by gender. ${ }^{109}$ Based on an analysis of the writing, the inscription has been dated to the period of Paul I's pontificate. ${ }^{10}$

The Roman tradition about the relics of St Sylvester is therefore connected to the pontificate of Paul I, who held the apostolic throne in the decade following King Aistulf's campaign against Rome. In my opinion, it is important to take this close time-frame into account. To sum up, according to the papal version of the story, Aistulf's Lombards devastated the cemetery areas around and outside the city, with the chief aim of pillaging them. During this looting, the Lombards also removed some relics and bodies of saints, whose names are not mentioned. Given the utter state of ruin of the sepulchres, and to avoid the complete deterioration of those precious relics, Paul I then decided to found the monastery of St Sylvester in Capite. Shortly after its founding, the pontiff also transferred there the bodies of the two titular saints of the monastery, St Sylvester and St Stephen. The fact that no mention is to be found of the translation performed by Anselm, along with the emphasis given specifically to the relics of St Sylvester, betrays the disposition of the Roman ecclesiastical authorities towards the Nonantolan claims: the translation, in their view, had never occurred and St Sylvester's relics had never left the Eternal City.

\section{A New Foundation Story for St Sylvester of Nonantola}

After the initial disputes in the second half of the eighth century, the controversy surrounding the relics of St Sylvester would appear to have cooled down, as the two contrasting positions became entrenched. While significant, the sources at our disposal do not allow us to clarify what really happened, that is, whether Sylvester's relics - as a whole or just a portion - were transferred from their original location on the Via Salaria to Nonantola in 756 or whether they were brought within the Aurelian walls, into the newly established Roman monastery of St Stephen, St Sylvester and St Dionysius in 761. But ultimately this is not the point.

In Rome, the version developed by Pope Paul I in the years just after Aistulf's expedition was laid down in its final form with the redaction of the $L P$, where it was featured within the account of the pontiff's life. By contrast, at Nonantola, probably between the tenth and the eleventh century - as we will now see - the need must have been felt to redevelop the original story of the translation of the saint, which was established with the text appended to the account of his life. Perhaps the urge to redevelop the tradition of the founding of the abbey was due to the need to counter the version endorsed by Pope Paul I in Rome. No doubt, the monks sought to consolidate the ideological claims made by their abbey, which aimed to reassert its pre-eminence within European Christendom, since the tenth century had brought a marked decline in its political and spiritual prestige compared to the previous century. ${ }^{111}$

108 Goodson, Rome of Pope Paschal I, 208; on Paul I’s policy towards relics, see ibid., 213-216.

109 Goodson, Rome of Pope Paschal I, 209-210.

110 Monumenta epigraphica, 37.1-2, ed. Silvagni. See Gray, Paleography, 52-53.

111 See Manarini, Politiche regie e attivismo, 58-74; Gelichi, Monastero nel tempo; Golinelli, Nonantola nella lotta. 
The text of the translatio Silvestri we are focusing on was probably composed on the basis of oral accounts and legends dating back to the period in which the monastery was founded. The text continued to be copied and regarded as useful - not least for liturgical purposes - up until the late tenth century, judging from the handwriting in the surviving manuscript. ${ }^{112}$ In the late Ottonian period, a moment of marked transition, the monastic community must have felt the need to redefine its identity-building discourse, which had hitherto rested on the hagiography of St Sylvester and on the founding of the monastery by Aistulf. The monks then established the sainthood of their first abbot, Anselm, by recording the Actus vel transitus Anselmi abbatis, ${ }^{113}$ but also by officially reserving a day in the liturgical calendar for his commemoration, 3rd March. The time frame for this process may be inferred from the agrarian contracts which the monastery drew up between 995 and 1019, where the rent day falls in March, rather than on the day of St Martin, on 11th November, as would have been customary. ${ }^{114}$

A new version of the translation of St Sylvester's relics - and hence too of the founding of the abbey - was inserted into the life of its founder Anselm, drafted in its final form around the mid-eleventh century, ${ }^{115}$ which is to say just a few decades after the text of the translatio Silvestri had been copied. In order to substantiate their account of the translation, this time the monks attributed a key role in this event to one of Paul I's successors, Pope Hadrian I (772-795): a widely renowned figure whose memory had become associated with the tradition of Carolingian power in Italy already in the years immediately after his death. ${ }^{116}$ The new tale inserted into the life of Anselm goes like this: while Pope Hadrian was in Rome, he was visited by the Lombard king Aistulf, who brought him various gifts for St Peter, including the praeceptum for the foundation of the monastery of Nonantola, which the king himself had granted Abbot Anselm not long before. The abbot himself was present and took the document and placed it on St Peter's body, thereby donating his monastery to the Church of Rome. The king then asked Hadrian to grant his brother-in-law the body of Pope Sylvester I. The pope agreed, consecrated Anselm as abbot, and placed Nonantola under the jurisdiction of the archbishop of Ravenna Sergius, as his representative. ${ }^{117}$

As far as our enquiry is concerned, the most striking fabrication in this new version is the fact that Aistulf's reign is said to coincide with Hadrian's pontificate. Actually, the whole narrative is built around the role played by Hadrian and the legitimating memory of him, which is used to support all the monks' claims about the relics and, more generally, in favour of the abbey's autonomy. Even the figure of the real founder of the monastery Anselm is de-emphasised in this new account, since he only plays a secondary role compared to Aistulf - the person responsible for founding the abbey and involving the pontiff - but also compared to Hadrian, who, through his munificence and authority, laid the foundations for the holiness and autonomy of Nonantola.

112 Golinelli, Agiografia e culto, 33.

113 BHL 541. According to Tomea, though, it must be dated not later than 974: Tomea, Intorno a S. Giulia, 32.

114 Tiraboschi, Storia dell'augusta badia 2, ns. 98,105,108,115. See Golinelli, Agiografia monastica, 24-25.

115 Golinelli, Agiografia monastica, 29.

116 Story et al., Charlemagne's Black Marble, 158. On Pope Hadrian I and Charlemagne, see Hartmann, Hadrian I. 117 Vita di sant'Anselmo, ed. Bortolotti, 257-259. 
In rewriting the history of its origins, the monastic community chose to add to the veneration of St Sylvester that of Pope Hadrian, whose body it also claimed to possess after the fortuitous circumstances of Pope Hadrian III's death near Nonantola in $885 .{ }^{118}$ The choice of this pope is hardly a matter of chance, because the figure of Hadrian I ensured an unexpressed yet direct link with Charlemagne's royal power: by including precisely this pope among the abbey's founders, the monks turned the Carolingian element into one of the original defining features of their identity. From this perspective of "mobility", the ideological discourse based on possession of the relics of St Sylvester may be seen to acquire a new meaning, by juxtaposing the first officially acknowledged pontiff of the Roman Empire to the pope who had enabled Charlemagne to build a new Christian empire through the stable control of the Italian kingdom. The abbey had sprung from Anselm's piety and King Aistulf's resources; and through the intervention of Pope Hadrian I it had acquired the bodies of saints that made it a unique site within Christendom: Constantine's pope, St Sylvester, and St Hadrian himself, Charlemagne's pope.

\section{Conclusion}

The case of translatio examined here is no doubt significant, yet at the same time contradictory. The translation of the relics of St Sylvester and the political and spiritual use of their holiness represent an instance both of mobility and of immovability, where both situations rest on specific reasons and claims, on the basis of which different authorities developed their identity-building and symbolic discourses for centuries.

First of all, what in a sense paved the way for the translatio was the Roman Church's creation of a tradition about Sylvester, collected in the $A S$, starting at the time of Symmachus' papacy in the early sixth century. The first versions of this tradition did not mention the issue of the pontiff's relics, since what mattered was rewriting the tale of Constantine's conversion, which, according to St Jerome, had involved the Arian faith - an idea that the Church of Rome found unacceptable. The ideological portrayal of Sylvester as the founder of Constantine's Christian empire was then relaunched by the Frank Carloman, who vied with his brother Pippin for the throne before withdrawing to monastic life: Carolingian sources associate him with the veneration of the holy pontiff on Mount Soratte. The connection between the Pippinids, who had just ascended the Frankish throne, and Sylvester was to bestow further symbolical legitimation on Pippin III's power.

It is at this point that the relics come into play. The Lombard king Aistulf and his brotherin-law both hedged their bets on their translation. The former, following the example of his predecessor Liutprand's use of St Augustine's relics, sought to strengthen his reign against the Frankish-papal alliance by establishing a direct connection with Constantine's Roman Christian imperial power. By bringing the corpus into his abbey, Anselm instead sought to make the monastery one of the foremost sites in Christendom: a God-enlightened crossroads where political power and sainthood coexisted harmoniously. This narrative was incorporated into the hagiographical text entitled translatio santi Silvestri, which was chiefly composed 
and preserved at Nonantola. The more successful project of the two was Anselm's one: his institution endured beyond Aistulf's reign, even acquiring new vigour after the Carolingian conquest. In Charlemagne's empire, Nonantola emerged as one of the great and powerful royal abbeys and came to be known as the place "in quo beatus Sylvester corpore requiescit «. ${ }^{119}$

By contrast, Pope Paul I hedged his bets on the immovability, or rather stability, of Sylvester's relics in Rome. By founding the monastery of Saints Sylvester and Stephen, he primarily sought to prevent the plundering of the bodies of martyrs and saints that Aistulf was to carry out during the 755/756 siege of Rome by bringing a large number of relics to safety inside the monastery walls. Secondly, Paul I sought to complete the papal version of the cult of St Sylvester by associating the AS's narrative with a concrete place, St Sylvester in Capite, where the faithful could see the saint's relics. The founding of this monastery also enabled the pontiff to reach an agreement with the Pippinids/Carolingians, who granted the pope exclusive control over the St Sylvester tradition in exchange for the full legitimation of their own royal power. Paul I thus added St Denis to Saints Sylvester and Stephen in the dedication of the monastery he had founded.

St Sylvester's relics were moved again as late as the beginning of the eleventh century. Faced with a new political and institutional situation, the monastic community of Nonantola felt the need to rewrite the history of its foundation, this time starting precisely from an account of the translation of the saint's relics featuring the direct involvement of Pope Hadrian I. The new veneration of this pontiff, which the monks associated with that of Sylvester and of their founder Anselm, constituted an attempt to paint the abbey's history in a new light, more suited to the eleventh century.

In the case just examined, then, St Sylvester's relics acquired different meanings depending on their state of mobility or immovability. In the face of the stability of the relics affirmed and established by the Church of Rome, the monks of Nonantola changed their identity-building discourse to suit new political requirements. However, there is one principle to which they always remained true: once brought within the abbey's walls, the body of St Sylvester was to ensure Nonantola's perpetual autonomy and independence from all secular powers.

\section{Acknowledgements}

An oral presentation of this work was delivered as a contribution to the strand "Movement and Mobility in Uncertain Times: Changing Perspective in the Mediterranean" in the context of the 6th Biennial Conference of the Society for the Medieval Mediterranean, held in Barcelona from 8th to 11th July 2019. I am grateful to Christopher Heath for co-organising that lively three-panel event, as well as editing these proceedings, also with the precious help of Clemens Gantner. I warmly thank both. I am indebted to Christopher Heath, Clemens Gantner, Dario Internullo, Tiziana Lazzari, Francesco Veronese, Giorgia Vocino, Giacomo Vignodelli for their helpful comments on earlier written drafts of this article. The views expressed are, of course, my own. 


\title{
References
}

\author{
Abbreviations \\ $\mathrm{BNF}=$ Biliothèque nationale de France \\ BHL $=$ Bibliotheca Hagiographica Latina \\ CC SL = Corpus Christianorum Series Latina \\ DD Kar I = Pippini, Carlomanni, Caroli Magni Diplomata \\ DD Lu I = Ludovici Pii Diplomata \\ $L P=$ Liber Pontificalis \\ MAAN = Musée provincial des Arts anciens \\ MGH = Monumenta Germaniae Historica \\ MGH SS = Monumenta Germaniae Historica Scriptores \\ MGT = Médiathèque du Grand Troyes \\ $\mathrm{KBR}=$ Royal Library of Belgium \\ RI 1 = Die Regesten des Kaiserreichs unter den Karolingern (751-918)
}

\section{Manuscripts}

Bamberg patr. 20.

Bruxelles, KBR 206.

Bruxelles, KBR 5519-5526.

Bruxelles, KBR 8515.

Namur, MAAN vil. 15 .

Nonantola, Acta Sanctorum.

Paris, BNF lat. 3788.

St Gallen 567.

Troyes, MGT anc. 7.

Acta Sanctorum, Septembris, (Antwerp, 1762).

Ammannati, Giulia, La lettera papiracea del Tesoro di Monza attribuita a Gregorio Magno: una nuova ipotesi, Studi medievali 45 (2004) 1051-1060.

Annales Fuldenses, ed. George Heinrich Pertz, MGH SS 1 (Hanover, 1826).

Annales Mettenses Priores, ed. Bernhard von Simson, MGH SS rer. Germ. 10 (Hanover, 1905). Annales Regni Francorum, ed. Friedrich Kurze, MGH SS rer. Germ. 6 (Hanover, 1895).

Bartlett, Robert J., Why Can the Dead Do Such Great Things? Saints and Worshippers from the Martyrs to the Reformation (Princeton, 2013).

Bede, De temporum ratione, ed. Charles W. Jones, CC SL 123B (Turnhout, 1977).

Becher, Matthias, Eine verschleierte Krise: Die Nachfolge Karl Martells 741 und die Anfänge der karolingischen Hofgeschichtsschreibung, in: Matthias Becher, Macht und Herrschaft: Praktiken - Strukturen - Begründungen (Göttingen, 2019) 261-290.

Bellelli, Lucia, I codici latini della »Passio sanctorum martyrum Theopompi episcopi et Theone«, in: Riccardo Fangarezzi, Paolo Golinelli and Alba Maria Orselli (eds.), Sant'Anselmo di Nonantola e i santi fondatori nella tradizione monastica tra Oriente e Occidente: Atti della giornata di studio, Nonantola 12 aprile 2003 (Rome, 2006) 281-285.

Bischoff, Bernard, Manoscritti nonantolani dispersi, La Bibliofilia 85 (1983) 99-124. 
Boaga, Emanuele, Il complesso titolare di S. Martino ai Monti in Roma, in: Mario Fois, Vincenzo Monachino and Felix Litva (eds.), Dalla Chiesa antica alla Chiesa moderna: Miscellanea per il cinquantesimo della Facoltà di Storia Ecclesiastica della Pontificia Università Gregoriana, Miscellanea historiae pontificiae 50 (Rome, 1983) 1-17.

Bortolotti, Pietro, Antica vita di sant'Anselmo abate di Nonantola, Monumenti di storia patria delle province modenesi: Serie delle cronache 14/2 (Modena, 1891).

Bougard, François and Vito Loré (eds.), Biens public, biens du roi : Les bases économiques des pouvoirs royaux dans le haut Moyen Âge (Turnhout, 2019).

Branchi, Mariapia, Lo scriptorium e la biblioteca di Nonantola (Modena, 2011).

Canella, Tessa, Gli Actus Silvestri: Genesi di una leggenda su Costantino imperatore, Uomini e mondi medievali 7 (Spoleto, 2006).

Canella, Tessa, I luoghi di culto negli Actus Silvestri: eremi o santuari?, Vetera Christianorum 47 (2010) 325-336.

Canella, Tessa, Gli Actus Silvestri tra Oriente e Occidente: Storia e diffusione di una leggenda costantiniana, in: Costantino I. Enciclopedia costantiniana sulla figura e l'immagine dell'imperatore del cosiddetto Editto di Milano 313-2013, 2 (Rome, 2013) 241-258.

Canella, Tessa, Storia e leggenda del santuario di San Michele al monte Tancia, con testo critico, traduzione e commento (Bari, 2020).

Catalogus codicum hagiographicorum latinorum Bibliothecae Regiae Bruxelliensis, 2 vols. (Brussels, 1886).

Capo, Lidia, Il Liber Pontificalis, $i$ Longobardi e la nascita del dominio territoriale della Chiesa romana, Istituzioni e società 12 (Spoleto, 2009)

Il chronicon di Benedetto e il Libellus de imperatoria potestate in Urbe Roma, ed. Giuseppe Zucchetti, Fonti per la storia d'Italia 55 (Rome, 1920).

Chronicon Salernitanum, ed. George Heinrich Pertz, MGH SS 3 (Hanover, 1839) 467-561.

Codex Carolinus, ed. Wilhelm Gundlach, MGH Epistolae 3 (Berlin, 1892) 469-657.

Concilia aevi Karolini, ed. Albert Werminghoff, MGH Concilia 2.1 (Hanover, 1906).

Constitutum Constantini, ed. Horst Fuhrmann, MGH Fontes Iuris 10 (Hanover, 1968).

Cosentino, Salvatore, Byzantine Sardinia between West and East. Feature of a regional culture, Millennium-Jahrbuch 1 (2004) 329-368.

De Leo, Pietro, Il Constitutum Constantini: compilazione agiografica del sec. VIII, Ricerche sui falsi medievali 1 (Reggio Calabria, 1974).

Delogu, Paolo, Lombard and Carolingian Italy, in: Rosamond McKitterick (ed.), The New Cambridge Medieval History 2: c.700-c.900 (Cambridge, 1995) 290-319.

De translatione sancti Silvestri, ed. Pietro Bortolotti, Antica vita di sant'Anselmo abate di Nonantola, Monumenti di storia patria delle province modenesi: Serie delle cronache 14/2 (Modena, 1891) 269-271.

Die Kanonessammlung des Kardinal Deusdedit 1: Die Kanonessammlung selbst, ed. Victor Wolf von Glanvell (Paderborn, 1905).

Die Regesten des Kaiserreichs unter den Karolingern (751-918), ed. Engelbert Mühlbacher and Johann Lechner, in: Johann Friedrick Böhmer (ed.), Regesta Imperii 1 (Innsbruck, 1908).

Di Muro, Alessandro, Uso politico delle reliquie e modelli di regalità longobarda da Liutprando a Sicone di Benevento, Mélanges de l'École française de Rome - Moyen Âge 132/2 (2020). Accessed on 23 December 2020: journals.openedition.org/mefrm/8193.

Einhard, Vita Karoli Magni, ed. Oswald Holder-Egger, MGH SS rer. Ger. 25 (Hanover, 1911). 
Ferrari, Guy, Early Roman Monastery: Notes for the History of the Monastery and Convents at Rome from the V through the X Century, Studi di antichità Cristiana 23 (Vatican City, 1957).

Fouracre, Paul J., The long shadow of the Merovingians, in: Joanna E. Story (ed.), Charlemagne: Empire and Society (Manchester, 2005) 5-21.

Fouracre, Paul J., The origins of the Carolingian attempt to regulate the cult of saints, in: Paul Antony Hayward and James D. Howard-Johnston (eds.), The Cult of Saints in Late Antiquity and the Middle Ages: Essays on the Contribution of Peter Brown (Oxford, 1999) 143-165.

Fried, Johannes, "Donation of Constantine « and »Consitutum Constantini (Berlin, 2007).

Frison, Carluccio, Note di storiografia medievale nonantolana: Alcune considerazioni in margine al "Catalogus abbatum Nonantulanorum«, in: Paolo Golinelli and Giorgio Malaguti (eds.), Nonantola nella cultura e nell'arte medievale (Bologna, 2003) 115-130.

Gantner, Clemens, The Lombard recension of the Roman "Liber Pontificalis«, Rivista di storia del cristianesimo 10 (2013) 65-114.

Gantner, Clemens, The eighth-century papacy as cultural broker, in: Clemens Gantner, Rosamond McKitterick and Sven M. Meeder (eds.), The Resources of the Past in Early Medieval Europe (Cambridge, 2015) 245-261.

Gasparri, Stefano, Italia longobarda. Il regno, i Franchi, il papato (Rome, 2012).

Gaudenzi, Augusto, Il monastero di Nonantola, il ducato di Persiceta e la Chiesa di Bologna, Bullettino dell'Istituto storico Italiano 36 (1916) 7-312.

Geary, Patrick Joseph, Furta sacra: Thefts of Relics in the Central Middle Ages (Princeton, 1990).

Geary, Patrick Joseph, Phantoms of Remembrance. Memory and Oblivion at the End of the First Millenium (Princeton, 1994).

Gelichi, Sauro, Il monastero nel tempo, in: Sauro Gelichi, Mauro Librenti and Alessandra Cianciosi (eds.), Nonantola 6 - Monaci e contadini, abati e re: Il monastero di Nonantola attraverso l'archeologia (2002-2009) (Sesto Fiorentino, 2018) 367-409.

Golinelli, Paolo, Agiografia e culto dei santi in un grande monastero: Nonantola nei secoli VIII-XII, in: Paolo Golinelli (eds.), Indiscreta sanctitas: Studi sui rapporti tra culti, poteri e società nel pieno medioevo, Studi storici 197-198 (Rome, 1988) 31-54.

Golinelli, Paolo, Nonantola nella lotta per le investiture: Da abbazia imperiale a monastero esente, in: Paolo Golinelli and Giorgio Malaguti (eds.), Nonantola nella cultura e nell'arte medievale (Bologna, 2003) 25-33.

Golinelli, Paolo, L'agiografia monastica nell'Italia settentrionale. Un esempio: la Vita Anselmi Abbatis Nonantulani, in: Giovanni Spinelli (ed.), Il monachesimo italiano dall'età longobarda all'età ottoniana (secc. VIII-X): Atti del VII Convegno di Studi Storici sull'Italia Benedettina, Nonantola (Modena), 10-13 settembre 2003 (Cesena, 2006) 17-38.

Goodson, Caroline J., The relic translation of Paschal I: Transforming city and cult, in: Andrew Hopkins and Maria Wyke (eds.), Roman Bodies: Antiquity to the Eighteenth Century (Rome, 2005) 123-141.

Goodson, Caroline J., Building for bodies: The architecture of saint veneration in early medieval Rome, in: Éamonn Ó Carragain and Carol Neuman de Vegvar (eds.), Felix Roma: The Production, Experience and Reflection of Medieval Rome (Farnham, 2008) 51-80.

Goodson, Caroline J., The Rome of Pope Paschal I: Papal Power, Urban Renovation, Church Rebuilding and Relic Translation, 817-824 (Cambridge, 2010).

Goodson, Caroline J., To be daughter of Saint Peter: S. Petronilla and forging the Franco-Papal alliance, in: Veronica West-Harling (ed.), Three Empires, Three Cities: Identity, Material Culture and Legitimacy in Venice, Ravenna and Rome, 750-1000, Seminari internazionali del SAAME 6 (Turnhout, 2015) 159-188. 
Goodson, Caroline J. and Janet L. Nelson, Review article: The Roman contexts of the "Donation of Constantine«, Early Medieval Europe 18/4 (2010) 446-467.

Goody, Jack, The Power of the Written Tradition (Washington-London, 2000).

Goosmann, Erik, Politics and penance: Transformations in the Carolingian perception of the conversion of Carloman (747) in: Clemens Gantner, Rosamond McKitterick and Sven M. Meeder (eds.), The Resources of the Past in Early Medieval Europe (Cambridge, 2015) 51-67.

Goosmann, Frederick C.W., Memorable Crises: Carolingian Historiography and the Making of Pippin's Reign, 750-900 (Amsterdam, 2013).

Gray, Nicolette, The paleography of Latin inscriptions in the eighth, ninth and tenth centuries in Italy, Papers of the British School at Rome 16 (1948) 38-162.

Gregory the Great, Dialogi 1, ed. Adalbert de Vogüé, Sources Chrétiennes 260 (Paris, 1979).

Guidobaldi, Federico, L'organizzazione dei tituli nello spazio urbano, in: Letizia Pani Ermini (ed.), Christiana loca. Lo spazio cristiano nella Roma del primo millennio 1 (Rome, 200o) 123-129.

Hallenbeck, Jan T., Pavia and Rome: The Lombard monarchy and the papacy in the eighth century, Transactions of the American Philosophical Society 72/4 (1982) 1-186.

Hallenbeck, Jan T., Rome under attack: An estimation of King Aistulf's motives for the Lombard siege of 756, Medieval Studies 40 (1978) 190-222.

Harrison, Dick, Political rhetoric and political ideology in Lombard Italy, in: Walther Pohl and Helmut Reimitz (eds.), Strategies of Distinction: The Construction of the Ethnic Communities, 300-800, Transformation of the Roman World 2 (Leiden, 1998) 241-254.

Hartmann, Florian, Hadrian I. (772-795): Frühmittelalterliches Adelspapsttum und die Lösung Roms vom byzantinischen Kaiser, Päpste und Papsttum 34 (Stuttgart, 2006).

Heath, Christopher, Aspects of movement and mobility in Lombard law: Fugitives, runaway slaves and strangers, Medieval Worlds 13 (2021) 13-35.

Heinzelmann, Michael, Translationsberichte und andere Quellen des Reliquienkultes (Turnhout, 1979).

Hilduin, Libro de sancto Dionysio, ed. Georg Waitz, MGH SS 15/1 (Hanover, 1887) 2-3.

Innes, Matthew, Introduction: using the past, interpreting the present, influencing the future, in: Yitzhak Hen and Matthew Innes (eds.), Using the Past in the Early Middle Ages (Cambridge, 2004) 1-8.

Jerome, Chronicon, ed. Rudolf Helm, Werke / Eusebius 7, Die griechischen christlichen Schriftsteller der ersten Jahrhunderte 47 (Berlin, 1956).

Lazzari, Tiziana, Patrimoni femminili, monasteri e chiese: una proposta (Italia centrosettentrionale, secoli VIII-X), in: Giovanna Petti Balbi and Paola Guglielmotti (eds.), Dare credito alle donne. Presenze femminili nell'economia tra medioevo ed età moderna. Convegno internazionale di studi: Asti, 8-9 ottobre 2010 (Asti, 2012) 25-36.

Lazzari, Tiziana, La tutela del patrimonio fiscale: pratiche di salvaguardia del pubblico e autorità regia nel regno longobardo del secolo VIII, Reti Medievali Rivista 18/1 (2017) 1-23.

Levison, Wilhelm, Konstantinische Schenkung und Silvesterlegende, in: Miscellanea Francesco Ehrle: Scritti di storia e paleografia 2 (Rome, 1924) 159-247.

Le Liber Pontificalis: Texte, introduction et commentaire, ed. Louis Duchesne, 2 vols. (Paris, 1886-1892).

Loré, Vito, Monasteri, re e duchi: modelli di relazione fra VIII e X secolo, in: Monachesimi d'Oriente e d'Occidente nell'alto medioevo II, Settimane di studio del CISAM 64 (Spoleto, 2017) 947-985.

Ludovici Pii Diplomata, ed. Theo Kölzer, MGH Diplomata Karolinorum 2 (Wiesbaden, 2016). 
Manarini, Edoardo, Politiche regie e attivismo nell'Emilia orientale: il monastero di S. Silvestro di Nonantola, Annali dell'Istituto italiano per gli studi storici 30 (2017) 7-74.

Manarini, Edoardo, Politiche regie e conflitti nell'Emilia orientale: il fisionomia del fisco regio, San Silvestro di Nonantola e le lotte per il regno dopo l'875, Reti Medievali Rivista 20/1 (2019) 121-156.

Maskarinec, Maya, City of Saints: Rebuilding Rome in the Early Middle Ages (Philadelphia, 2018).

McKitterick, Rosamond, Constructing the past in the early Middle Ages: The case of the Royal Frankish Annals, Transactions of the Royal Historical Society 7 (1997) 101-129.

McKitterick, Rosamond, The Frankish Kingdoms under the Carolingians, 751-987 (London,1983).

McKitterick, Rosamond, History and Memory in the Carolingian World (Cambridge, 2004).

McKitterick, Rosamond, Charlemagne, Rome and the management of sacred space, in: Rolf Große and Michel Sot (eds.), Charlemagne: les temps, les espaces, les hommes. Construction et déconstruction d'un règne, Collection Haut Moyen Âge 34, (Turnhout, 2018) 165-179.

McKitterick, Rosamond, Rome and the Invention of the Papacy: The Liber pontificalis (Cambridge, 2020).

Mombritius, Boninus, Sanctuarium sive Vitae Sanctorum, fac., 2, ed. Henri Quentin and Albin Brunet (Paris, 1910) 508-531.

Monumenta epigraphica christiana seculo XIII antiquiora quae in Italiae finibus adhuc exstant, ed. Angelo Silvagni (Rome, 1938-1943).

Nelson, Janet L., Gender and genre in women historians of the Early Middle Ages, in: Janet L. Nelson (eds.), The Frankish World, 750-90o (London, 1996) 183-197.

Noble, Thomas F. X., The Republic of St. Peter: The Birth of the Papal State, 680-825 (Philadelphia, 1984).

Pani Ermini, Letizia, La Sardegna nel periodo vandalico, in: Massimo Guidetti (ed.), Storia dei Sardi e della Sardegna, I: Dalle origini alla fine dell'età bizantina (Milano, 1988) 297-327.

Parente, Maria and Loretta Piccinini (eds.), Lo splendore riconquistato: Nonantola nei secoli XIXII. Rinascita e primato culturale del monastero dopo le distruzioni (Modena, 2003).

Paul the Deacon, Historia Langobardorum, ed. Ludwig Conrad Bethmann and Georg Waitz, MGH SS rer. Lang. (Hanover, 1878) 12-187.

Pauli diaconi continuatio tertia, eds. Ludwig Conrad Bethmann and Georg Waitz, MGH SS rer. Lang. (Hanover, 1878) 203-216.

Pippini, Carlomanni, Caroli Magni Diplomata, ed. Engelbert Mühlbacher, MGH Diplomatum Karolinorum 1 (Hanover, 1906).

Pohlkamp, Wilhelm, Tradition und Topographie: Papst Silvester I. (314-335) und der Drache vom Forum Romanum, Römische Quartalschrift für christliche Altertumskunde und für Kirchengeschichte 78 (1983) 1-100.

Pohlkamp, Wilhelm, Kaiser Konstantin, der heidnische und der christliche Kult in den Actus Silvestri, Frühmittelalterliche Studien 18 (1984) 357-400.

Pollard, Richard M., "Libri di scuola spirituale«: Manuscripts and marginalia at the monastery of Nonantola, in: Lucio Del Corso and Oronzo Pecere (eds.), Libri di scuola e pratiche didattiche: Dall'Antichità al Rinascimento, Atti del Convegno Internazionale di Studi, Cassino, 7-10 maggio 2008 (Cassino, 2010) 331-408.

Regesta Pontificum Romanorum, ed. Philippe Jaffé, Samuel Loewenfeld, Ferdinand Kaltenbrunner and Paul Ewald, 1 (Leipzig, 1885).

Regesto del monastero di S. Silvestro de Capite, ed. Vincenzo Federici, Archivio della società romana di storia patria 22 (1899) 213-300. 
Ricciardi, Alberto, Re e aristocrazia alla metà del secolo VIII: il cambio dinastico del 751 nella prospettiva dell'Historia vel Gesta Francorum, in: Maria Pia Alberzoni and Roberto Lambertini (eds.), Autorità e consenso: Regnum e monarchia nell'Europa medievale, Ricerche. Storia. Ordines 5 (Milan, 2017) 135-161.

Ropa, Giampaolo, Agiografia e liturgia a Nonantola nel medioevo, in: Riccardo Fangarezzi, Paolo Golinelli and Alba Maria Orselli (eds.), Sant'Anselmo di Nonantola e i santi fondatori nella tradizione monastica tra Oriente e Occidente: Atti della giornata di studio, Nonantola 12 aprile 2003 (Rome, 2006) 41-61.

Scorza Barcellona, Francesco, Silvestro I, santo, in: Massimo Bray (ed.), Enciclopedia dei Papi (Rome, 2000). Accessed on 23 December 2020: www.treccani.it/enciclopedia/santo-silvestro-i_\%28Enciclopedia-dei-Papi\%29/.

Smith, Julia, Aedificatio sancti loci: The making of a ninth-century holy place, in: Mayke de Jong and Frans C. Theuws (eds.), Topographies of Power in the Early Middle Ages, Transformation of the Roman World 6 (Leiden, 2001) 361-396.

Smith, Julia, Care of relics in early medieval Rome, in: Valerie Louise Garver and Owen M. Phelan (eds.), Rome and Religion in the Medieval World: Studies in Honor of Thomas F. X. Noble (Farnham, 2004) 176-206.

Stone, Harold Samuel, St. Augustine's Bones: A Microhistory (Boston, 2002).

Story, Joanna, Judith Bunbury, Anna Candida Felici, Gabriele Fronterotta, Mario Piacentini, Chiara Nicolais, Daria Scacciatelli, Sebastiano Sciuti and Margherita Vendittelli, Charlemagne's black marble: The origin of the epitaph of Pope Hadrian I, Papers of the British School at Rome 73 (2005) 157-190.

The Lives of the Eighth-Century Popes, trans. Raymond Davis, Translated Texts for Historians 13 (Liverpool, 2007).

Tiraboschi, Girolamo, Storia dell'augusta badia di S. Silvestro di Nonantola, 2 vols. (Modena, 1784).

Tomassetti, Giuseppe, Della campagna romana nel medio evo 3 (Rome, 1885).

Tomea, Paolo, Intorno a S. Giulia: Le traslazioni e le "rapine« dei corpi santi nel regno longobardo (Neustria e Austria), in: Giancarlo Andenna (ed.), Culto e storia a Santa Giulia (Brescia, 2001) 29-101.

Tomei, Paolo and Giacomo Vignodelli (eds.), $A$ »Dark Matter«: History and Archaeology of Fiscal Estates in Medieval Italy (8th-11th c.) (forthcoming).

Translatio Sancti Silvestri, ed. Pietro Bortolotti, Antica vita di sant'Anselmo abate di Nonantola, Monumenti di storia patria delle province modenesi: Serie delle cronache 14/2 (Modena, 1891) 272.

Van Espelo, Dorine, A testimony of Carolingian rule? The Codex epistolaris carolinus, its historical context, and the meaning of imperium, Early Medieval Europe 21/3 (2013) 254-282.

Veronese, Francesco, Tra rispetto delle leggi e furti notturni, Mélanges de l'École française de Rome - Moyen Âge, 132/2 (2020). Accessed on 23 December 2020: journals.openedition. org/mefrm/8396\#bodyftn12.

Veronese, Francesco and Giulia Zornetta, Holiness on the move: Relic translations and the affirmation of authority on the Italian edge of the Carolingian World, Medieval Worlds 13 (2021) 54-75.

Vita di sant'Anselmo, ed. Pietro Bortolotti, Antica vita di sant'Anselmo abate di Nonantola, Monumenti di storia patria delle province modenesi: Serie delle cronache 14/2 (Modena, 1891) 255-263. 
Vocino, Giorgia, Le traslazioni di reliquie in età carolingia (fine VIII-IX secolo): uno studio comparativo, Rivista di storia e letteratura religiosa 44 (2008) 207-255.

Wirbelauer, Eckhard, La riche mémoire d'un évêque de Rome méconnu, Silvestre, in: Philippe Blaudeau and Peter Van Nuffelen (eds.), L'historiographie tardo-antique et la transmission des savoirs, Millennium Studies 55 (Berlin, 2015) 319-332.

Wood, Ian N., The Merovingian Kingdoms, 450-751 (London, 1994). 